\title{
Glucosidase Inhibitor
}

National Cancer Institute

\section{Source}

National Cancer Institute. Glucosidase Inhibitor. NCI Thesaurus. Code C2846.

Any substance that inhibits glucosidase, specifically alpha-glucosidase in the brush border of the small intestines, an enzyme that catalyzes the breakdown of carbohydrates to simple sugars. Inhibition of glucosidase reduces and delays the effects of ingested carbohydrates on blood sugar. 